\author{
ONDERZOEKSRAPPORT NR 9004 \\ FORE IGN DIRECT INVESTMENT AND \\ INTRA - F IRM TRADE: \\ EV I DENCE FROM JAPAN \\ BY \\ L. SLEUWAEGEN \& H. YAMAWAK I
}




\title{
Foreign Direct Investment and Intra-Firm Trade: Evidence from Japan
}

\section{LEO SLEUWAEGEN}

\author{
Catholic University of Leuven, Belgium \\ Erasmus University, Rotterdam, The Netherlands
}

and

\section{HIDEKI YAMAWAKI}

Science Center Berlin, W. Germany

The paper benefitted from comments by Jagdish Bhagwati, Peter Dicken, Theo Peeters and Luc Soete.

Partial financial support of the Research Fund of the K.U. Leuven $(\mathrm{OT} / 89 / 5)$ is gratefully acknowledged. 


\section{INTRODUCTION}

One of the most remarkable developments in the post-war period is the strong growth in the activities of multinational corporations (MNC). Within this process firms are operating more and more on a global scale and pursue an optimal international spread of their activities. In most cases this implies international intra-firm specialization, by which vertically related activities are geographically dispersed across national boundaries. Consequently, intra-firm trade becomes increasingly important in international transactions. It was estimated that in the early eighties MNC already represented, excluding the centrally planned economies, about 80 to 90 percent of world trade with about two fifths of all international trade transactions through intra-firm transfers (Clairmonte and Cavenagh (1982), p. 3, UNCTNC (1988)).

MNC can hardly be described as ordinary mobile factors of production. Technological know-how, marketing expertise and organizational experience are key elements in the bundle of resources that are transferred between the multinational parent companies and their subsidiaries abroad. The intangible and firm-specific nature of these operations poses specific problems in analyzing the behaviour of MNC. Recently trade theorists have started to integrate the specific nature of the operations of MNC into general equilibrium models. In doing so, Helpman and Krugman (1985) show how MNC and intra-firm trade will develop under specific international structures of factor endowments. Wilfred Ethier (1986) further develops the new theory in endogeneizing the decision to internalize transactions within the company. Contrary to Helpman and Krugman he finds that the more similar 
factor endowments are between countries, the more multinational companies will develop and the more intense intra-company trade will take place. However, as Ethier in his innovative paper admits, some of the results may be specific to the way he has modelled the internalization decision.

This paper does not try to adopt an integrative approach, but illustrates from a partial equilibrium point of view some key elements behind the intra-firm trade decisions of Japanese MNC. In Section 2 the basic motives to integrate vertically across national boundaries are discussed. Among other market imperfections, protectionism by national governments may play an important role in intra-firm trade, as is illustrated within the confines of a formal model in the Appendix to this paper.

Section 3 discusses the importance and main characteristics of intra-firm trade by Japanese MNC. In Section 4 intra-firm trade by Japanese corporations is studied in relation to Japanese direct investment in distribution. Section 5 concludes the paper.

\section{VERTICAL INTEGRATION AND THE REGULATION PARADOX}

Intra-firm trade basically reflects integration of vertically linked activities within the firm across national borders. The theory of vertical integration explains the advantages and disadvantages of internalizing transactions and markets within the firm. It explains why the internal coordination of different stages of production and distribution is preferred above the coordinating role of an open market. It follows that 
when upstream or downstream activities are optimally located in different countries, vertical integration will lead to the development of multinational corporations and to intra-firm trade in intermediate products and services (Baldwin 1988). In essence, the theory states that vertical integration will occur when total profits from two or more stages of production and distribution integrated within one firm are higher than when these different stages are performed by independent firms. Formally:

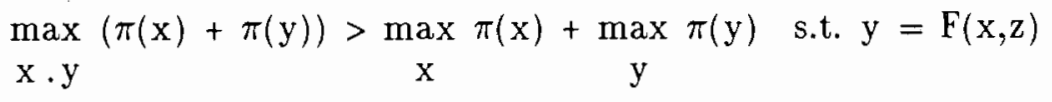

where $\pi$ is profit, $\mathrm{x}$ and $\mathrm{y}$, are intermediate and final product, respectively, and $\mathrm{z}$ represents all other inputs.

Following this logic, Blair and Kaserman (1983) describe five basic motives for vertical integration: optimal appropriation of quasi-rents from the exploitation of firm-specific assets, avoiding incomplete contracts, eliminating abuse of sequential market power, obtaining implicit insurance and minimizing transaction costs. These motives will typically occur with transactions dealing with intangible or complex goods or services, such as the (un-embodied) results of past (sunk) R\&D investments. From these observations it is not surprising that vertical integration and the development of multinational corporations is typical in technology - and resource -intensive industries.

While the foregoing motives could be typified as natural market imperfections there exists an equally important number of unnatural 
government-created market imperfections which give rise to vertical integration. International differences in profit tax rates, tariffs, and in laws concerning patents, licensing or direct investment regulations such as inter alia, local content requirements, enforced joint-ventures, may substantially affect the international (vertical) integration decision of multinational corporations. Through intra-company trade with transfer prices different from arm length prices MNC can exploit - or defend against - these international differences.

Similarly, with strict regulations or enforced joint ventures, transfer prices become an important instrument for MNC to extract the maximum of profits from the regulated operations. As a consequence, intra-firm trade strategies by MNC may lead to trade behaviour very different from open market trading (see Goldsbrough (1982)). This leads to a regulation paradox. With governments starting to regulate part of the operations of a MNC, they may stimulate intra-firm trading, necessitating more and more specific regulation of transfer prices. These regulations may counteract (macro-economic) adjustment flexibility and lead to trade reactions by MNC whereby they more further and further away from the welfare optimum that was originally envisaged by the local government.

In addition to tariff of tax measures there exists many non-tariff barriers to international trade thay may equally stimulate intra-firm trade. Typical examples are the different technical barriers embedded in national regulations on products. These different regulations imply international differences in standards and certification. As a consequence of these barriers, international corporations are forced to adapt their product to 
local conditions, necessitating in many cases, the set up of assembly plants in the different countries. Similarly, government procurement policies may favour companies with productions activities located in the country concerned. In short, these various tariff- and non-tariff barriers simulate intense intra-firm trade and/or lead to specific direct investments in the different countries. This is formally developed within the framework of an oligopoly model in the Appendix of this paper. The model assumes that non-tariff trade barriers increase the costs of exporting companies through making it necessary to undertake extensive investments in downstream distribution or service activities in the foreign country. Depending on the nature of the trade barriers, increased protection may lead to a substitution of exports for direct investment in the protective country. The model emphasizes the role of the potential market in this substitution process. The faster the markt grows and the higher are trade barriers, the more exports will be substituted by local manufacturing in the foreign country. As a consequence intra-firm trade linked with foreign market protection will change and reduce in magnitude.

\section{THE IMPORTANCE AND PATTERN OF INTRA-FIRM TRADE}

MNC dominate world trade. For instance, in the United States they accounted for over three quarters of U.S. exports and for almost one half of U.S. imports in 1983. In the United Kingdom MNC were responsible for over eighty

per cent of exports in the early 1980's. Not all this trade is intra-firm trade. The share of intra-firm trade is substantially below the share of 
open market trade for home country MNC in the U.S., U.K. or Japan. In these countries Intra-firm exports associated with all MNC center around thirty per cent of all exports (column 3). The share of intra-firm imports is markedly higher in the U.S. which seems to be primarily due to the growing U.S. market penetration by foreign investors. For U.S. based MNC the share of intra-firm imports is falling.

As can be seen in table 2 intra-firm trade tends to concentrate in high-technology industries and in those producing complex manufactures. These categories of goods require important after-sales service, which explains why they are marketed through whole-sale subsidiaries of the exporting companies.

A good proportion of intra-firm trade is in parts and components of more complex goods, and relates to a new international division of labour. According to the nature of the activity and to fully reap economies of scale, production of a particular component is concentrated in one (attractive location) country from where the component is shipped to plants in the home country or other countries where further manufacturing takes place. Given that they are in a more advanced stage of the transnationalization process, this new division of labour would indeed seem to be more typical for U.S. based MNC, than for Japanese MNC.

The share of intra-firm imports in total imports by US MNC, is substantially higher than for Japanese MNC. The rising importance of foreign affiliates in the global operations of US based MNC may also be derived from table 3 , which shows the importance of exports by parent 
companies and foreign affiliates in terms of world exports.

\section{TABLE 1: THE IMPORTANCE OF INTRA-FIRM TRADE}

\section{COUNTRY}

1985

Japan

Exports

1980

1983

Imports

1980

1983

United Kingdom

Exports

1981
SHARE OF INTRA-FIRM TRADE (Percentage)

IN NATIONAL TRADE

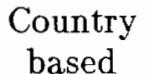

MNC

(1)

26.7

21.9

29.0

21.7

17.1

15.1

Foreign
based
MNC

(2)

2.6

1.1

2.0

20.5

21.3

24.0

1.7

1.2

10.6

11.9

31.5

18.4

16.0

14.0

30.0
All MNC

(3)

29.3

23.0

31.0

42.2

38.4

40.1

25.8

31.8

42.1

30.3

Source: United Nations Centre on Transnational Corporations (1988) 


\section{TABLE 2:SHARE OF INTRA-FIRM TRADE IN EXPORTS AND IMPORTS ASSOCIATED WITH HOME-COUNTRY TRANSNATIONAL CORPORATIONS, EARLY 1980s}

(Percentage)

\begin{tabular}{|c|c|c|c|c|c|}
\hline \multirow[b]{2}{*}{ Industries } & \multicolumn{2}{|c|}{ United States (1982) } & \multicolumn{2}{|c|}{ Japan (1983) } & \multirow{2}{*}{$\begin{array}{l}\text { United Kingdom (1981) } \\
\text { Exports }\end{array}$} \\
\hline & Exports & Imports & Exports & Imports & \\
\hline All Industries & 32.9 & 40.8 & 23.7 & 27.7 & 27.0 \\
\hline Petroleum & 23.4 & 24.1 & $42.4^{\mathrm{a}}$ & $28.8^{\mathrm{a}}$ &.. \\
\hline Mining &.. &.. & 4.5 & 11.5 & .. \\
\hline Manufacturing & 38.6 & 63.0 & 29.9 & 20.9 &.. \\
\hline Foods and & & & & & \\
\hline Beverages & 19.3 & 22.0 & 18.3 & 2.3 & 27.4 \\
\hline Textiles &.. &.. & 2.7 & 5.2 &.. \\
\hline $\begin{array}{l}\text { Wood, paper } \\
\text { and pulp }\end{array}$ &.. &.. & 0.4 & 22.0 & \\
\hline Chemicals & 36.4 & .. & 19.5 & 8.0 & 48.1 \\
\hline Metals & 16.7 & .. & $2.2^{\mathrm{b}}$ & $1.8^{\mathrm{b}}$ & 21.5 \\
\hline $\begin{array}{l}\text { Non-elec- } \\
\text { trical }\end{array}$ & & & & & \\
\hline $\begin{array}{l}\text { machinery } \\
\text { Electrical }\end{array}$ & 51.4 & 74.2 & 12.8 & 20.0 & .. \\
\hline machinery & 32.5 & 55.7 & 24.8 & 41.9 & .. \\
\hline $\begin{array}{l}\text { Transport } \\
\text { equipment } \\
\text { Precision }\end{array}$ & 43.6 &.. & 45.3 & 34.3 & $49.8^{c}$ \\
\hline $\begin{array}{l}\text { instruments } \\
\text { Other }\end{array}$ & .. & .. & 38.7 & 32.1 & .. \\
\hline $\begin{array}{l}\text { manufacturing } \\
\text { Wholesale }\end{array}$ & g 36.2 & 42.8 & .. & .. & 18.3 \\
\hline $\begin{array}{l}\text { trade } \\
\text { Other }\end{array}$ & 12.2 & 12.8 & 18.2 & 30.6 & .. \\
\hline industries & 24.6 & 49.4 & 12.3 & 22.1 & 21.2 \\
\hline
\end{tabular}

Source: United Nations Centre on Transnational Corporations, based on official national sources (1988).

a Petroleum and coal products.

b Iron and steel.

c Motor vehicles. 


\section{TABLE 3: EXPORTS OF MANUFACTURES BY TRANSNATIONAL CORPORATION IN THE UNITED STATES AND JAPAN, AS A PERCENTAGE OF WORLD EXPORTS OF MANUFACTURES (Percentage)}

\begin{tabular}{|c|c|c|c|c|c|c|}
\hline \multirow[b]{2}{*}{ Year } & \multicolumn{3}{|c|}{ United States } & \multicolumn{2}{|c|}{ Japan } & \multirow[b]{2}{*}{$\begin{array}{l}\text { Affiliate } \\
\text { exports }\end{array}$} \\
\hline & $\begin{array}{l}\text { MNC- } \\
\text { related } \\
\text { exports }\end{array}$ & $\begin{array}{l}\text { Parents } \\
\text { exports }\end{array}$ & $\begin{array}{r}\text { Affiliate } \\
\text { exports }\end{array}$ & $\begin{array}{l}\text { MNC- } \\
\text { related } \\
\text { exports }\end{array}$ & $\begin{array}{l}\text { Parents } \\
\text { exports }\end{array}$ & \\
\hline 1966 & 17.7 & 11.0 & 6.7 & - & - & - \\
\hline 1974 & - & - & - & 7.4 & 6.6 & 0.8 \\
\hline 1977 & 17.6 & 9.2 & 8.4 & - & - & - \\
\hline 1983 & 17.7 & 9.1 & 8.6 & 9.9 & 9.3 & 0.6 \\
\hline 1984 & 18.1 & 9.2 & 8.9 & - & - & - \\
\hline
\end{tabular}

Source: United Nations Centre on Transnational Corporations (1988).

These findings suggest that U.S. based corporations are increasingly operating on a global scale, and use their competitive advantages in conjunction with comparative advantages present in the different countries in which they operate (see also Lipsey and Kravis (1982)). The data for the U.S. contrast with those for Japan, where companies recently started to expand production across national frontiers much more. A recent study by Dunning and Pearce (1985) found that for a rationalised sample of firms in 1982, the overseas market sourcing ratio (= share of foreign production in total foreign sales) of Japanese MNC only equalled 19 percent while for US MNC the figure equalled 84 percent.

Table 4 shows indeed that Japanese intra-firm imports as a percentage of total sales of parents, is very small, mostly less than one percent. The ratio is higher in natural resource intensive industries such as wood and 
paper and non-ferrous metal industries. The role of Asian subsidiaries in machinery and precision instruments is also noteworthy and reflects a growing international division of labour within the Japanese MNC.

TABLE 4: EXPORTS OF FOREIGN SUBSIDIARIES TO JAPANESE PARENTS, (A) AS A PERCENTAGE OF TOTAL SALES OF PARENTS AND (B) AS A PERCENTAGE OF SALES BY FOREIGN SUBSIDIAIRIES IN THE DIFFERENT REGIONS, 1984 (\%)

Location of subsidiary

Industry United States EC Asia World Total
(a) (b)
(a) (b)
(a) (b)
(a)
(b)

\begin{tabular}{|c|c|c|c|c|c|c|c|c|}
\hline Food & 0.4 & 22.1 & 0.0 & 0.2 & 0.1 & 8.6 & 0.6 & 16.0 \\
\hline Textiles & 0.0 & 0.1 & 0.0 & 0.0 & 0.5 & 3.9 & 0.5 & 3.0 \\
\hline \multicolumn{9}{|c|}{ Wood and Paper } \\
\hline Products & 0.5 & 49.6 & .. & .. & 0.3 & 35.0 & 3.5 & 44.3 \\
\hline Chemicals & 0.2 & 40.1 & 0.0 & 2.0 & 0.1 & 4.6 & 0.4 & 9.7 \\
\hline Iron and & & & & & & & & \\
\hline $\begin{array}{l}\text { Steel } \\
\text { Non-Ferrous }\end{array}$ & 0.0 & 3.3 & 0.0 & 0.0 & 0.2 & 7.3 & 0.2 & 4.0 \\
\hline Metal & 0.0 & 0.0 & 0.0 & 2.3 & 0.0 & 0.3 & 2.4 & 21.2 \\
\hline Machinery & 0.0 & 0.8 & 0.0 & 0.0 & 0.2 & 13.5 & 0.2 & 10.6 \\
\hline $\begin{array}{l}\text { Electrical } \\
\text { machinery }\end{array}$ & 0.7 & 1.1 & 0.0 & 4.1 & 0.5 & 16.0 & 0.6 & 6.0 \\
\hline $\begin{array}{l}\text { Transportation } \\
\text { equipment } \\
\text { Precision }\end{array}$ & 0.0 & 0.1 & 0.0 & 0.0 & 0.1 & 3.7 & 0.7 & 2.6 \\
\hline instruments & 0.0 & 0.2 & 0.0 & 3.1 & 0.9 & 27.9 & 2.0 & 19.6 \\
\hline Others & 0.0 & 0.3 & 0.0 & 0.1 & 0.2 & 5.3 & 0.2 & 2.7 \\
\hline $\begin{array}{l}\text { Manufacturing } \\
\text { total }\end{array}$ & 0.1 & 4.8 & 0.0 & 1.2 & 0.2 & 8.1 & 0.6 & 9.7 \\
\hline
\end{tabular}

Source: Ministry of International Trade and Industry, Kaigai toshi tokei soran : No. 2 (The 2nd Statistical Report on Foreign Investment), Tokyo : Keibunshuppan, 1986. 
Another distinctive pattern of Japanese intra-firm trade is that Japanese manufactures use local distribution subsidiaries more extensively to market their products. As Table 5 indicates, U.S. distribution subsidiaires of Japanese firms act as a major channel for intra-firm trade.

TABLE 5: IMPORTS BY FOREIGN AFFILIATES IN THE US, MAJOR SECTOR BY COUNTRY OR REGION OF ORIGIN, 1986

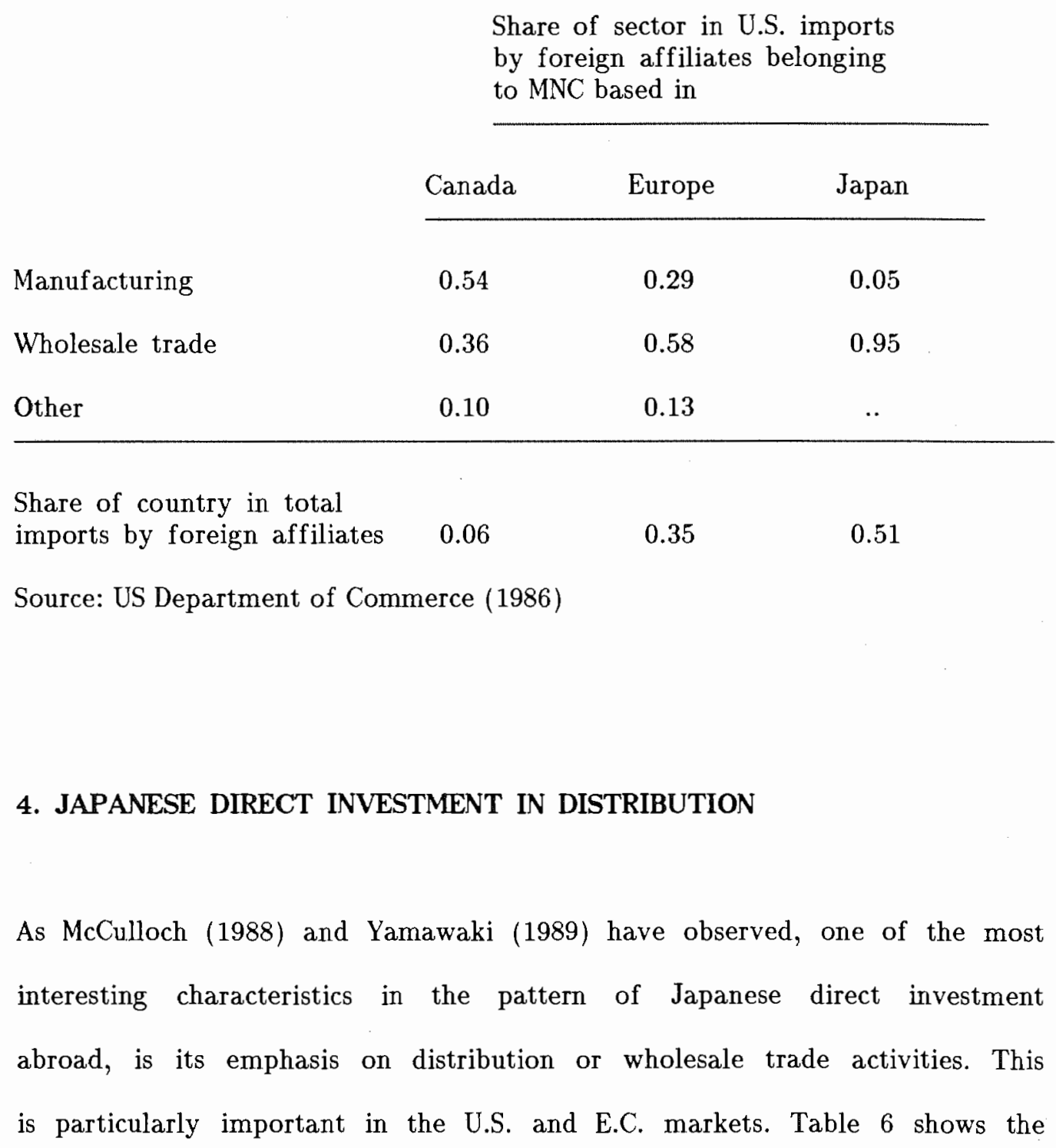


TABLE 6:DISTRIBUTION OF JAPANESE SUBSIDAIRIES ACROSS INDUSTRY 1986 BY REGION (\%)

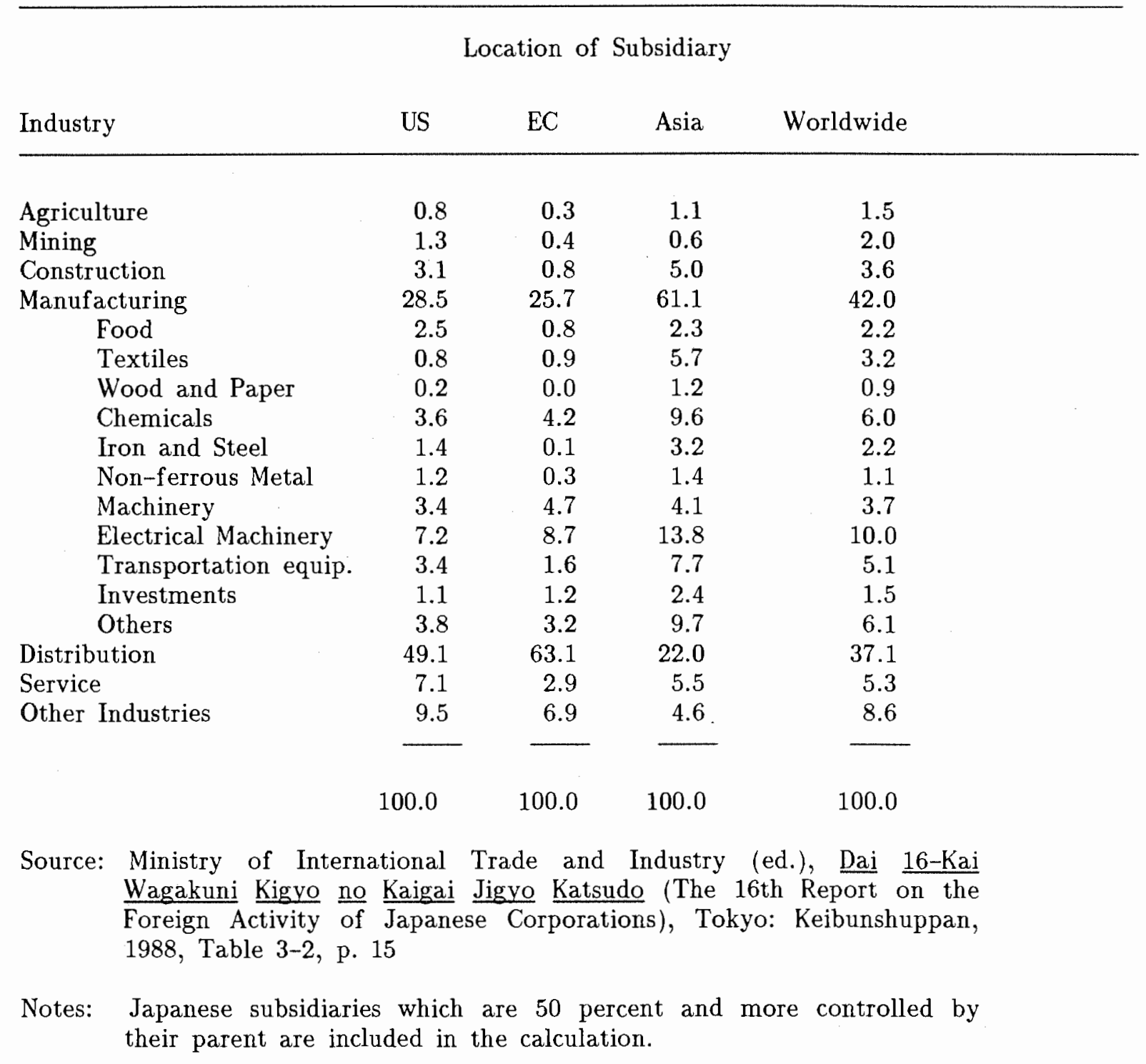


distribution of Japanese subsidiaries across industries by regions measured in the number of Japanese subsidiaries in distribution as a percentage of the total number of Japanese subsidiaries in each region. Thus, in the U.S. markets, 49 per cent of the Japanese subsidiaries are in the distribution sector, and in the E.C. markets, 63 per cent of the Japanese subsidiaries are in the distribution sector. By contrast, in the Asian countries, the importance of direct investment in distribution is lower, while the importance of direct investment in manufacturing is higher. Thus, the fraction of total employees in Japanese subsidiaries engaged in distributional activities in the U.S. and E.C. is larger than that worldwide (The Fourth column in Table 6). This distinctive pattern of Japanese direct investment in U.S. and E.C. markets implies that the subsidiary of the Japanese multinational corporation not only produces the parent's goods for the local markets, but also organizes a distribution system and provides customer service in the local markets. The relatively high concentration of Japanese direct investment in distributional activities may reflect Japanese firms' organizational strategy in their home market. In fact, Williamson and Yamawaki (1989) have found that Japanese manufacturers have integrated forward into wholesaling more strongly than typical US firms in pharmaceuticals, electrical machinery and household appliances, professional and scientific instruments, pottery, and furniture. Japanese automobile companies, meanwhile, show the highest forward integration into wholesaling of any industry in Japan (Table 7).

Having found the distinctive pattern of Japanese direct investment, we now seek its determinants focusing on the choice between local production and imports through local distribution subsidiaries. A survey conducted by the 
TABLE 7: SHARE AT WHOLESALE TRADE PERFORMED BY MANUFACTURER SUBSIDIARY, THE UNITED STATES AND JAPAN

Industry United States $\mathscr{\%} \quad$ Japan $\%$

Fabric

Women's \& Child, Apparel

45.3

Furniture

Paper \& Allied

26.5

17.8

48.5

Chemicals

74.0

Pharmaceuticals

0.7

Pottery

5.7

17.1

Metal Products

44.4

59.6

34.0

48.9

Other Electric Machinery

Automobiles \& Parts

41.5

30.8

Instruments

40.6

14.8

19.1

40.5

26.3

36.0

61.6

22.5

18.7

45.5

66.9

51.5

70.1

38.7

Toys \& Sporting Goods

35.7

41.1

31.7

Average

39.0

Source: Adapted from Williamson and Yamawaki (1989), Table 1, p.2. 
Ministry of International Trade and Industry in Japan and summarized in Table 8 shows that "to deal with trade friction" is the major reason why Japanese MNC set up production subsidiaries in industrialized countries, whereas low production costs are the most important incentive to produce in developing countries.

\section{TABLE 8: MOTIVES FOR JAPANESE FIRMS SEEKING PRODUCTION BASES OVERSEAS}

$\begin{array}{lllllll}\text { Motives }(\%)^{\mathrm{a}} & & & & \\ 1 & 2 & 3 & 4 & 5 & 6\end{array}$

Industrialised countries

Office Equipment

Machine tools

Home electric appliances

Electronics

Automobiles

Developing countries

Textiles

Chemicals

Ferrous/nonferrous metals

Home electric appliances

Electronics

$\begin{array}{rrrrrr}96.7 & 3.3 & - & - & - & - \\ 77.1 & 14.3 & - & - & 5.0 & 3.6 \\ 53.6 & 13.6 & 10.7 & 14.3 & 2.8 & 5.0 \\ 30.0 & 32.1 & 11.3 & 10.8 & 8.8 & 7.1 \\ 66.0 & 24.0 & - & - & - & 10.0\end{array}$

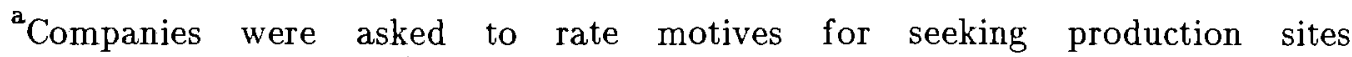
overseas, assuming $100 \%$ as their total motives. Results were then summed by industry and by region. The motives are coded as follows: 1 To deal with trade friction; 2 To secure or expand oversead market for reasons not related to trade friction; 3 To respond to moves overseas by customer companies; 4 To take advantage of lower production costs overseas; 5 To hedge risks related to exchange rate fluctuations; 6 Others.

Source: Ministry of International Trade and Industry, 1986, as reproduced in Dicken (1988). 
These motives are consistent with the pattern of intra-firm trade disucssed in the previous section. To identify the determinants of the choice between local production and imports through local distributional subsidiaries, we use a statistical model that regresses the share of employment in U.S. distribution by Japanese MNCs on a set of explanatory variables. These variables are explained in Table 9 and in the appendix. The major hypothesis to be tested is that the presence of trade barriers encourage local production and discourage imports through local distributional subsidiaries. 
TABLE 9: VARIABLE DEFINITION, MEAN AND STANDARD DEVIATION $(\mathrm{N}=43)$

SYMBOL VARIABLE

MEAN/(STANDARD

DEVIATION)

\begin{tabular}{|c|c|c|}
\hline DISTJ & $\begin{array}{l}\text { Employment in Japanese Distribution Subsi- } \\
\text { diaries in U.S./Total Employment in Japanese } \\
\text { subsidiaries in U.S. } 1986\end{array}$ & $\begin{array}{c}0.489 \\
(0.372)\end{array}$ \\
\hline EXPJUS & $\begin{array}{l}\text { Japanese Exports to U.S./Total U.S. Sales, } \\
1986\end{array}$ & $\begin{array}{l}0.075 \\
0.131)\end{array}$ \\
\hline KLJ & $\begin{array}{l}\text { Gross Fixed Assets/Total Employment, Japan } \\
1984\end{array}$ & $\begin{array}{c}5.287 \\
(4.528)\end{array}$ \\
\hline GRUS & $\begin{array}{l}\text { Change in Shipments 1976-84/Shipment } 1976 \text {, } \\
\text { U.S. }\end{array}$ & $\begin{array}{c}0.901 \\
(0.742)\end{array}$ \\
\hline RDUS & Cost of Company R\&D/Sales, U.S., 1977 & $\begin{array}{c}0.022 \\
(0.020)\end{array}$ \\
\hline ADUS & Media Advertising Expenses/Sales, U.S., 1977 & $\begin{array}{c}0.017 \\
(0.019)\end{array}$ \\
\hline HUFB & $\begin{array}{l}\text { Hufbauer's }(1970) \text { proxy for product differen- } \\
\text { tiation: the coefficient of variation of unit } \\
\text { values of U.S. exports among various destination } \\
\text { countries, } 1965\end{array}$ & $\begin{array}{c}0.972 \\
(0.360)\end{array}$ \\
\hline TARIFF & $\begin{array}{l}\text { Nominal Rate of Tariff. Protection, Post-Tokyo } \\
\text { Round, U.S. }\end{array}$ & $\begin{array}{c}4.107 \\
(3.275)\end{array}$ \\
\hline TRNUS & $\begin{array}{l}\text { Weiss's (1972) proxy for tranportation costs: } \\
\text { mile radius within which } 80 \% \text { of industry ship- } \\
\text { ments were made }\end{array}$ & 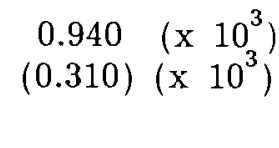 \\
\hline NONTAR & $\begin{array}{l}\text { Non-tariff barrier index, U.S., ad valorem } \\
\text { equivalent, } 1984\end{array}$ & $\begin{array}{c}1.500 \\
(3.889)\end{array}$ \\
\hline QDUM & $\begin{array}{l}\text { Dummy variable equal to one if the industry is } \\
\text { subject to quantitative trade restrictions }\end{array}$ & $\begin{array}{c}0.140 \\
(0.351)\end{array}$ \\
\hline CDUM & $\begin{array}{l}\text { Dummy variable equal to one if the industry is } \\
\text { judged to sell primarily consumer } \\
\text { non-convenience goods }\end{array}$ & $\begin{array}{c}0.372 \\
(0.489)\end{array}$ \\
\hline SEM & $\begin{array}{l}\text { Sales divided by employment in U.S. manu- } \\
\text { facturing, } 1982 \text { ( } \$ \text { million })\end{array}$ & $\begin{array}{l}1.055 \\
(0.0693)\end{array}$ \\
\hline SED & $\begin{array}{l}\text { Sales divided by employment in U.S. distribution } \\
150,1982 \text { ( } \$ \text { million })\end{array}$ & $\begin{array}{c}4.116 \\
(3.575)\end{array}$ \\
\hline
\end{tabular}


By using the share of employment in U.S. distribution as the dependent variable we are not suggesting that local manufacturing does not require investment in distribution. However, because local manufacturing requires less investment in distribution and in view of the fact that the denominator comprises employment in Japanese subsidiaires in distribution as well as in manufacturing, the dependent variable strongly reflect the substitution of exports for local production in the U.S. industry.

Table 7 reports the regression results. In line with the theoretical model in the appendix, a growing market in the United States and high transportation costs favour local production more than imports through local distributional subsidiaries. Since the model is designed to explain the relative importance of distributional activity in total Japanese direct investment in the United States by using employment as a proxy for investment, there should be a control for technological differences between the manufacturing and distribution activities. However, the three control variables, KLJ, SEM and SED are not statistically significant.

The recent finding by Yamawaki (1989) that distributional activities promote exports from Japan to the U.S. market, along with the argument that distributional activities are subject to substantial scale economies (Williamson and Yamawaki, 1989), suggest that there will be relatively less investment in distribution as the ratio of Japanese exports to total U.S. sales becomes larger. Thus, EXPJUS has a negative coefficient.

Technological intensity and Hufbauer's measure of product differentiation; 
are positively correlated with the degree of Japanese investment in U.S. distribution relative to manufacturing. Industries producing primarily non-convenience consumer goods also display relatively more investment in distribution. However, with other product differentiation features controlled for, industries characterized by high advertising in the U.S. display relatively less Japanese investment in distribution. As to the role of trade friction variables, non-tariff trade barriers mostly involve specific adaptations to local market conditions and require specific servicing. Consequently, the higher are these trade barriers, the larger are the investments in distribution activities encompassing these service activities. Different from the effect of the non-tariff variable, high nominal tariffs and import quantity restrictions, lead to a substitution of exports from Japan in favour of local production in the U.S. market. This result is clearly in line with our a priori hypothesis about the effects of trade restricting measures. Equation (2) shows the impact on the estimation results of leaving out trade friction variables. Only the coefficient of R\&D changes markedly and becomes significantly different from zero, suggesting collinearity between $R \& D$ intensity and the various protective measures. 


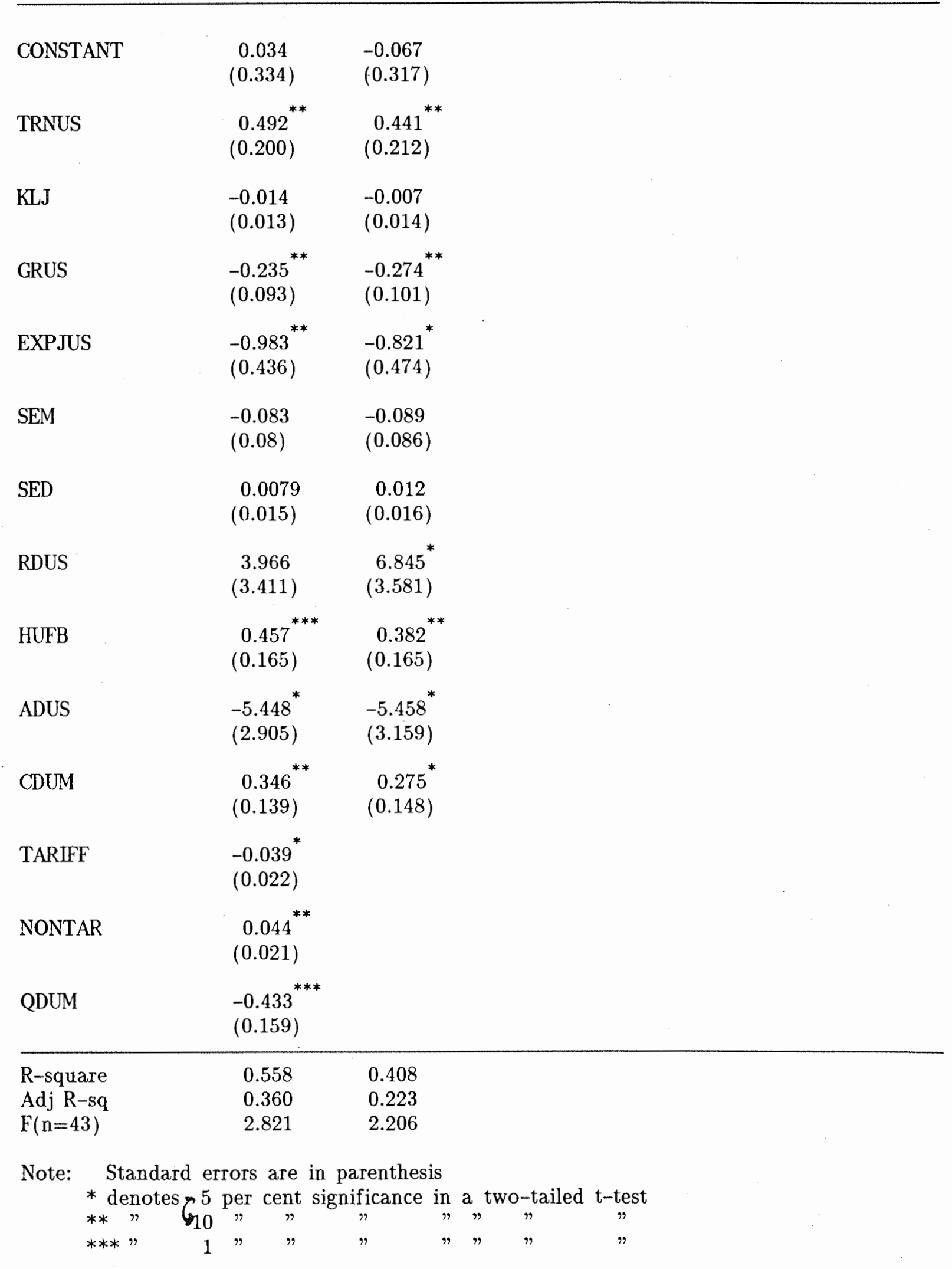




\section{CONCLUSION}

The paper explained intra-firm trade as the result of vertical integration of firms across national boundaries. In looking at the different motives for vertical integration it was argued that government intervention may lead to important "unnatural" market imperfections which stimulate firms to use intra-firm trade as a mechanism to take advantage or defend against these imperfections.

By contrasting data on Japanese intra-firm trade with intra-firm trade data for U.S. firms, it was found that Japanese parent import relatively less from their foreign affiliates and strongly direct their intra-firm exports to their foreign distribution subsidiaries in the U.S. and Europe. Empirical evidence for Japanese subsidiaries in the U.S. suggest that this kind of intra-firm trade reduces in magnitude and becomes substituted by local manufacturing when the market grows, transportation costs become more important and trade restrictions increase.

Finally, most of the Japanese intra-firm trade pattern can be explained by the fact that the expansion of Japanese firms in global markets is of much more recent origin than is the case for U.S. or European firms. It is very likely that this pattern will change in the future and converge to the situation within U.S. or European firms along with further world integration of markets. 


\section{APPENDIX}

The model we propose presents a simple characterization of protectionism within the context of an oligopoly model. By its simple nature the model allows us to explicit some basic effects of protectionistic measures upon economic variables, such as price, distribution of market shares, the importance of intra-firm trade and the extent of foreign direct investment in the industry.

In line with Richard Baldwin (1988) we envisage protectionism in relation two kinds of cost raising measures: those which raise the marginal cost of supplying the product or service and those which raise the fixed cost of controlling a foreign firm (such as the various regulations concerning direct investment). The first category may include import tariffs, but also various kinds of non-tariff barriers, such as inter alia, the different kind of technical regulations on products or services for which local adjustment necessitates the location of downstream services in the foreign country which raise marginal supply costs. In the model these marginal cost raising barriers are denoted by $\tau$, while the specific fixed cost incurred in local production by foreign companies is denoted by F. Most of the non-tariff barriers are not intended to raise government revenue. With trade barriers present, trade will be internalized within firms ans foreign firms will face constant marginal cost $c_{i}(1+\tau)$, for these export transactions. To keep the model simple, we assume that relevant marginal cost is also $\mathbf{c}_{\mathbf{i}}$ if they produce locally in the foreign market. However in the latter case they incur a (recurrent) specific cost $F$, because of possible discriminating measures against foreign producers and the various 
expenses associated with operating in an unfamiliar environment.

The model assumes Cournot-Nash equilibrium outcomes for $\mathrm{N}$ producers. The Nash-equilibrium in quantities is defined as

$$
\pi_{i}\left(\mathrm{q}_{\mathrm{i}}^{*}\right) \geq \pi\left(\mathrm{q}_{\mathrm{i}}^{*} \ldots, \mathrm{q}_{\mathrm{i}-1}^{*}, \mathrm{q}_{\mathrm{i}} \ldots \mathrm{q}_{\mathrm{N}}^{*}\right) \forall \mathrm{q}_{\mathrm{i}}, \forall \mathrm{i}
$$

Define three sets of firms: $S_{D}$ the set of the domestic producers, $S_{x}$ the set of the exporters and $S_{F}$ the set of all foreign producers with local production in the market, profit functions are:

$$
\begin{array}{rlr}
\pi_{i} & =P(Q) q_{i}-c_{i} q_{i} & \forall i \varepsilon S_{D} \\
\pi_{i} & =P(Q) q_{i}-c_{i}(1+\tau) q_{i} & \forall i \varepsilon S_{X} \\
\pi_{i} & =P(Q) q_{i}-c_{i} q_{i}-F & \\
\text { where } Q & =\Sigma i \varepsilon S_{F} \\
& i \varepsilon S_{D} \mathrm{US}_{X} q_{i} &
\end{array}
$$

With only import tariffs present, the MNC will chose marginal cost $c_{i}$ as the optimal transfer price, given that this is the lowest possible transfer price tax authorities will accept. It is also important to notice that in the decision process $S_{X}$ and $S_{F}$ are the same. Assuming constant marginal costs, the equilibrium implies corner solutions with either exports or 
foreign production equal to zero. Therefore, in discussing the equilibrium conditions, only active exporters from the set $\mathrm{S}_{\mathrm{x}}$ and active foreign producers from $S_{F}$ will be considered. These subsets are denoted by $\mathrm{S}_{\mathrm{X}}^{+}$and $\mathrm{S}_{\mathrm{F}}^{+}$. Active domestic producers are denoted by $\mathrm{S}_{\mathrm{D}^{+}}^{+}$. By imposing the restriction that $\mathrm{P} '<0, \mathrm{P}^{\prime} \mathrm{q}_{\mathrm{j}}<0$ it has been shown that there exists a stable and unique Cournot-Nash equilibrium (Dierickx, Matutes and Neven (1987)). At any equilibrium point $\mathrm{q}_{\mathrm{i}}^{*}>0$ we have

$$
\begin{array}{ll}
\mathrm{P}+\frac{\partial \mathrm{P}}{\partial \mathrm{Q}} \mathrm{q}_{\mathrm{i}}^{*}-\mathrm{c}_{\mathrm{i}}=0 & \forall \mathrm{i} \varepsilon \mathrm{S}_{\mathrm{D}}^{+} \mathrm{US} \mathrm{S}_{\mathrm{F}}^{+} \\
\mathrm{P}+\frac{\partial \mathrm{P}}{\partial \bar{Q}} \mathrm{q}_{\mathrm{i}}^{*}-\mathrm{c}_{\mathrm{i}}(1+\tau)=0 & \forall \mathrm{i} \varepsilon \mathrm{S}_{\mathrm{X}}^{+}
\end{array}
$$

These conditions can be reformulated as follows:

$$
\begin{array}{lc}
P\left(1-\frac{s_{i}}{\eta}\right)-c_{i}=0 & \forall i \varepsilon S_{D}^{+} U_{F}^{+} \\
P\left(1-\frac{s_{i}}{\eta}\right)-c_{i}(1+\tau) & \forall i \varepsilon S_{X}^{+}
\end{array}
$$

where $s_{i}=\frac{q_{i}^{*}}{Q^{-}}$, market share of firm i.

Summing over the active firms, and using the constraint, $\Sigma \mathrm{s}_{\mathrm{i}}=1$, yields the following price equation:

$$
\mathrm{P}=\overline{\mathrm{c}}\left(\frac{\eta}{\eta-\frac{1}{\mathrm{~N}}}\right)
$$


where $\overline{\mathrm{c}}=\frac{1}{\mathrm{~N}}\left\{\sum_{\mathrm{i} \varepsilon \mathrm{S}_{\mathrm{D}} \mathrm{US}_{\mathrm{F}}} \mathrm{c}_{\mathrm{i}}+\sum_{\mathrm{i} \varepsilon \mathrm{S}_{\mathrm{X}}}^{\sum_{\mathrm{i}}} \mathrm{c}_{\mathrm{i}}(1+\tau)\right), \mathrm{N}$ being the number

active suppliers in the market. In words, $\bar{c}$ is the (unweighted) average marginal cost of all suppliers. Inserting (17) into (15) and (16) we obtain the following market share functions

$$
\begin{array}{ll}
\mathrm{s}_{\mathrm{i}}=\eta-\left[\eta-\frac{1}{\mathrm{~N}}\right] \frac{\mathrm{c}_{\mathrm{i}}}{\overline{\mathrm{c}}} & \forall \mathrm{i} \varepsilon \mathrm{S}_{\mathrm{D}}^{+} \mathrm{US}_{\mathrm{F}}^{+} \\
\mathrm{s}_{\mathrm{i}}=\eta-\left[\eta-\frac{1}{\mathrm{~N}}\right] \frac{\mathrm{c}_{\mathrm{i}}(1+\tau)}{\overline{\mathrm{C}}} & \forall \mathrm{i} \varepsilon \mathrm{S}_{\mathrm{X}}^{+}
\end{array}
$$

From condition (17) it may be verified how trade barriers summarized in $\tau$ increase price, restrict demand, and, as equation (19) shows, take away market share from exporters. The equilibrium conditions also enable us to calculate 'effective' measures of protection, in the sense that they totally impede export penetration by foreign producers. With a given number of domestic firms $\mathrm{N}$, characterized by average marginal cost $\bar{c}$, exports will effectively be impeded as long as $\mathrm{p}-\mathrm{c}_{\mathbf{i}}(1+\tau)<0(20)$, or given price equation (17), $\left(\frac{\bar{c}}{c_{i}}+\frac{1}{N}\right)\left(\frac{N \eta}{<N+1>\eta-1}\right)<1+\tau(21)$, for all potential exporters. Condition (21) implies that (non-) tariff barriers have to be high enough to compensate for the higher marginal cost of domestic firms vis-à-vis any potential foreign exporter. For demand elasticities larger than one, the more elastic the demand curves become, the less protection will be needed. The effect of changing the number of firms depends on the magnitudes of the cost differential and demand elasticity. 
As an alternative way of penetrating the market, foreign companies might decide to invest and produce locally in the market. In this case protectionism would still have to focus on making specific adjustments or servicing of the product necessary, or on increasing $F$, the specific cost foreign inventors incur in operating foreign plants. In order to operate on a profitable scale, MNC need to attain a market share large enough to compensate for this specific cost F. Formally, if profitability (profits $\pi_{i}$, divided by revenues, $R_{i}$ ) has to be positive, it is necessary that,

$$
\frac{\pi_{i}}{R_{i}}=\frac{\left(p-c_{i}\right) q_{i}}{p q_{i}}-\frac{F}{p q_{i}}>0,(22), \text { which implies, using (15) }
$$

$\frac{\mathrm{s}_{\mathrm{i}}}{\eta}-\frac{\mathrm{F}}{\mathrm{pq_{ \textrm {i } }}}>0$, or $\mathrm{s}_{\mathrm{i}}>\mathrm{V}_{\overline{\mathrm{pQ}}} \mathrm{F} \cdot \eta(23)$, where $\mathrm{pQ}$ is the size of the market.

Formula (23) can be further developed by calculating potential market share $\mathrm{s}_{\mathrm{i}}$ from (18) and total market size from (17), with the provision that $\overline{\mathrm{c}}$ now includes $c_{i}$, the marginal cost of the potential foreign firm and with the number of firms extended to $\mathrm{N}+1$. Given this information, F, which effectively impedes entry by a foreign firm, may be calculated. Important to note from condition (23) is that the size of the market as summarized in $\mathrm{pQ}$, is an important determinant for direct investment to take place. With the assumptions made in this model, foreign production will always yield larger market share and larger price-marginal cost margins than exporting to the protected market. It follows that the timing of foreign direct investment to substitute exports, in this model is basically explained by the growth of the foreign market. Obviously, the model could be extended by introducing different marginal cost conditions in the home and the foreign 
country for the MNC, and by allowing for fixed costs for domestic as well as for foreign firms. These extensions would undoubtedly refine the analysis, but not alter the basic insights obtained so far.

$\underline{\text { Japanese direct } \underline{\text { investment }} \underline{\text { in }} \underline{\text { US }} \text { distribution. Selection of Samples }}$

The matched manufacturing industries used in this paper were selected on the basis of the standard industry classification system in Japan and the United States. The level of industry classification is comparable to the 3-digit U.S. SIC. The 43 industries in our sample were those industries where Japanese multinationals control (50\% or more) their distribution subsidiaries in the United States.

\section{$\underline{\text { Sources of Data }}$}

DISTJ was constructed from Toyokeizal (ed.), Kalgalshlnshulsn Klgyu soran: 1988 (directory of Japanese Multinational Corporations 1988, Tokyo, Tokyokeizai). This data source publishes the number of employees in each subsidiary in the U.S. by line of business. Thus, the number of employees in Japanese subsidiaries at the industry level was constructed by aggregating the figure for the line of business. EXPJUS was constructed from Japan External Trade Organization (JETRO), White Paper on International Trade Japan. KLJ and total Japanese shipments were obtained from Japan, Ministry of International Trade and Industry, Census of Manufactures. GRUS was constructed from U.S. Bureau of Census, Census of Manufactures, RDUS and ADUS were obtained from U.S. Federal Trade Commission, Annual Line of Business $\underline{\text { Report, }}$ 1977. HPDUS was obtained from 
Dany C. Hufbauer, "The Impact of National Characteristics and Technology on the Commodity Composition of Trade in Manufactured Goods", in R. Vernon (ed.), The Technology Factor in International Trade (New York: NBER, 1970). NOTUS,TARIFF was obtained from Alan V. Deardorff and Robert R. Stern, "The Effects of the Tokyo Round on the Structure of Protection", in R.E. Baldwin and A.O. Krueger (eds.), The Structure and Evolution of Recent U.S. Trade Policy (Chicago: The University of Chicago Press, 1984) and Alan V. Deardorff and Robert R. Stern, "Alternative Scenarios for Trade Liberalization", Seminar Discussion Paper, No. 217, Department of Economics, The University of Michigan, Ann Arbor, Michigan. The data were available for only 21 broadly defined industries, so we assumed that the value for each was common for each of the 43 industries included within it. Finally, TRNUS was obtained from Leonard W. Weiss, "The Geograpic Size of Markets in Manufacturing", Review of Economics and Statistics 54 (August, 1972), pp. 243-257, and is a weighted average of the 4-digit shipping radius. SEM and SED were obtained from the U.S. Census of Industry, 1982 and the 1982 Census of Wholesale Trade, respectively. 


\section{REFERENCES}

Baldwin, R., "Factor Market Barriers are Trade Barriers: Gains from Trade in 1992", Columbia Business School, mimeo, April 1988.

Bhagwati, J., Protectionism, The M.I.T. Press, Cambridge, MA, 1988.

Blair, R. and D. Kaserman, Law and Economics of Vertical Integration and Control, Academic Press, New York, 1983.

Brander, J.A. and B.J. Spencer, "Trade Warfare: Tariffs and Cartels", Journal of International Economics, 16, 227-242, 1984.

Casson, M. and associates, Multinationals and World Trade, Allen and Unwin, London, 1986.

Clairmonte, F. and J. Cavenagh, "The Ever-Grasping Drive", Development Forum, November 1982, 3-4.

Dicken, P. "The Changing Geography of Japanese Foreign Direct Investment in Manufacturing Industry: A Global Perspective", Environment and Planning A, 20, 633-653, 1988.

Dierickx, I., C. Matules and D. Neven, "Indirect Taxation and Cournot Equilibrium, INSEAD, mimeo, July 1987.

Dunning, J.H. and R.D. Pearce, The World Largest Industrial Enterprises, Gower Press, Farnborough, Hants, 1985.

Ethier, W. "The Multinational Firm", Quarterly Journal of Economics, 101, 805-833, 1986.

Goldsborough, D., "International Trade of Multinational Corporations and its Responsiveness to Changes in Aggegate Demand and Relative Prices", I.M.F. Staff Papers, 18, 573-599, 1981.

Helleiner, G.K., Intra-Firm Trade and the Developing Countries, Macmillan, London, 1981.

Helpman, E. and P. Krugman, Market Structure and Foreign Trade, M.I.T. Press, Cambridge, MA, 1985.

Horst, T., "The Theory of the Multinational Firm: Optimal Behavior under Different Tariff and Tax Rates", Journal of Political Economy, 79, 1059-1072, 1971.

Kent, C., "Endogenous Transfer Pricing and the Effects of Uncertain Regulation", Journal of International Economics, 254, 147-157, 1988.

Kreps, D. and J.A. Scheinkman, "Quantity Precommitment and Bertrand 